\title{
Characteristics and Identification of Critical Points of Halal Food at Restaurants in Padang
}

\author{
Anni Faridah ${ }^{1 *}$, Rahmi Holinesti ${ }^{2}$, Wirnelis Syarif ${ }^{3}$, Mohd Salehuddin Mohd Zahari ${ }^{4}$ \\ ${ }^{1,2,3}$ Faculty of Tourism and Hospitality, Universitas Negeri Padang, Jl. Prof. Dr. Hamka, Air Tawar Padang, \\ Padang, Sumatera Barat 25131, Indonesia \\ ${ }^{4}$ Faculty of Hotel and Tourism Management, Universiti Teknologi MARA, Selangor, Malaysia \\ e-mail: faridah.anni@fpp.unp.ac.id ${ }^{* 1}$, r.holinesti@gmail.com ${ }^{2}$, wirnelissyarif@fpp.unp.ac.id ${ }^{3}$, \\ salehuddinm@uitm.edu.my ${ }^{4}$
}

*Corresponding Author

Received: August 04, 2021; Accepted: February 27, 2022

\begin{abstract}
Padang is one of the cities in Indonesia with a majority of the Moslem population. It is a crucial thing to be considered by Moslems. This study aims to determine the critical point of halal food found at restaurants in the city of Padang as the novelty of this study. In this study, qualitative methods are used with a population of all restaurants in the city of Padang. The research sources data were informants or restaurant managers by using purposive sampling techniques. The data research was observations and interviews with informants and documentation. Data processing in this study used NVivo 11 software and it is descriptively equipped with data reduction, data presentation, and conclusion making. The result of this research show there are two dominant cooking techniques used in food processing; 65 dishes for frying and 37 dishes for boiling with coconut milk. The food processing using the burned technique, boiled with water, and sautéed are little. There are three types of beverages served; mineral water, sachet drinks (tea, coffee, cappuccino), and fruit processed (fruit juices) as the beverages menu. Identification results show the critical point of halal food in restaurants are divided into four; 1) high water content (beef, chicken, offal, Tempe, and tofu), 2) low water content (salt, sugar, flavoring, sachets, flour, rice flour, paneer flour, and crackers), 3) liquid raw materials (mineral water, cooking oil, soy sauce, and vinegar), and 4) processing equipment (brush polish). Food ingredients and processing equipment that have a critical halal point are meat, crackers, bulk oil, mineral water, and brushes. While other Food Materials, unique packaged ones, already have a halal label on the packaging. This research can contribute in providing information to Moslems about the importance of halal food from all aspects as good as facilitate the restaurant to get halal certification.
\end{abstract}

Keywords: characteristics, identification, critical halal point, restaurants.

\section{Introduction}

Halal comes from an Arabic word. It means legal and permitted for consumption following Islamic law (Neio Demirci et al., 2016; Olya \& Al-Ansi, 2018). Halal food have to be free from components that come from humans, non-halal animals such as pigs and dogs, or animals that are not slaughtered according to Islamic methods or contain the dirtiness (Yusaini et al., 2016). Based on Law of Republic Indonesia number 33 of 2014 article four explains that products that enter circulation and trade within the territory of Indonesia must be halal-certified. Restaurants decree processed a variety of foods. It must carry out the activities to ensure halal foods and beverages produced and traded. The activities that must be guaranteed halal. It is the provision of materials (raw materials and additives), processing, equipment used, storage, packaging, distribution, sales, and serving of food and beverages traded in the restaurant (Neio Demirci et al., 2016).

According to Adawiyah and Kulsum 2019, a critical point is a point in processing process, which causes halal materials or halal food become Haram (forbidden). A critical point of halal products can be seen from their products according to Islamic law and additives which do not use illicit products. For guarantee halal products, it is need to know the critical point of halal products traded in the restaurants (Lau et al., 2016).

The restaurant is one of the culinary industries. They have a critical halal point on traded food and beverages. The restaurant is any commercial place of business whose scope of activities is to provide food and drinks for the public at its place of business (Srivastava, 2015). An awareness and commitment of halal restaurants in Indonesia are still far. It happened at restaurants in Padang, which still have little halal certification (LPPOM-MUI, 2018). 
Research conducted by Halal Watch, the official agency that advocates and protects consumers to obtain halal products in the community shows 3081 restaurants in Indonesia, only $1.49 \%$ have halal certificates from MUI. In West Sumatra, only 22 restaurants and restaurants have halal certification (Perdana, 2019).

Padang is one of the major cities in Indonesia. According to Colombijn (1996), Minangkabau is the leading ethnic group, and Islam is the majority religion of the population. Minangkabau culture is affected by Islam as evidenced by the philosophy of Minang namely "Adat Basandi Syarak, Syarak Basandi Kitabullah" It means that the Minangkabau tradition is appropriate with Islamic law Al-Quran (Sovia et al., 2018). Islamic Foundation which is embraced by people in Padang has not been guaranteed, but for traded food is automatically Halal guaranteed. Broaden technology and information obscures halal food processing. It causes food products in the restaurant in Padang have to be identified. It is caused by the lack of research sources.

The identification of the critical point of halal food in Padang restaurant is the aim of this study. Determination of the critical halal point of the product is essential as a reference for processing food products and the development of a halal guarantee system manual to certify food products traded in restaurants. This research also can be further information for Moslems who concern about halal food.

\section{Materials and Methods}

This research used descriptive qualitative research methods. Aspers \& Corte (2019) explains that qualitative research is one of the research procedures to obtain descriptive data in written or oral words from observable individuals. The sources data were informant and restaurant managers. The sampling technique used purposive sampling technique by categorizing restaurants based on the number of menus served, named large restaurants (number of menus $>45$ ), medium (number of menus 16 to 44 ), and small (number of menus $<15$ ). The number of restaurants as samples is 31 outlets. They are ten percent from the category (Arikunto, 2019).

Data collection technique was observation and interviews as same as observations of research location. All data collected was analyzed thematically by using Nvivo 11 software and supplemented with data reduction, data presentation, and conclusion (Miles et al., 2019). Thematic analysis is one of the more flexible ways to identify, analyze, and report qualitative research data. Before enrolling the data into Nvivo 11 analysis tool, the interviewees were recorded, clustered, and eased for being reporting theme (Maguire \& Delahunt, 2017).

\section{Results and Discussion}

\subsection{Characteristics of Restaurants}

\subsubsection{Restaurants Category}

Analysis of the hierarchy chart of nodes is performed on nodes' restaurant to determine the number of menus in each restaurant as for categorizing the restaurants (Figure 1). Figure 1 shows that the Ampalu Raya restaurant (47 menus) and Sederhana Restaurant (45 menus) are large-group restaurants. Keluarga Restaurant (23 menus), Ranah Bunda (22 menus), Pak Golak (21 menus), Ajo Arip (20 menus), Lapau Nasi Bunda (19 menus) Barasaki Dadok Tunggul Hitam (19 menus), Tanjung Indah (18 menus), Awak Basamo (18 Menus), Ampera Parkit (18 menus), Manggaraya (17 menus), Ampera Ajo (17 menus), and Ayang (16 menus) are middle-class restaurants. Rumah Makan Ikan Bakar Simpang Transito (15 menus), Goyang Baru Basalero (15 menus), Rasokan Dulu (13 menus), Cendrawasih (14 menus), Empat Dara (13 menus), Bumbu Kampuang (13 menus), Ampera Yakin (13 menus), Ampera Gunung Pangilun (13 menus), Ampera Bunda (13 menus), Talago Suryo (12 menus), Bintang Mulia (12 menus), Ampera Sari Nikmat (12 menus), Nasi Kapau Sutan (11 menus), Beringin (11 menus), Taman Surya (10 menus), Ampera Ibu Tunggul Hitam ( 8 menus), and Ampera Murni (7 menus) are small groups. 


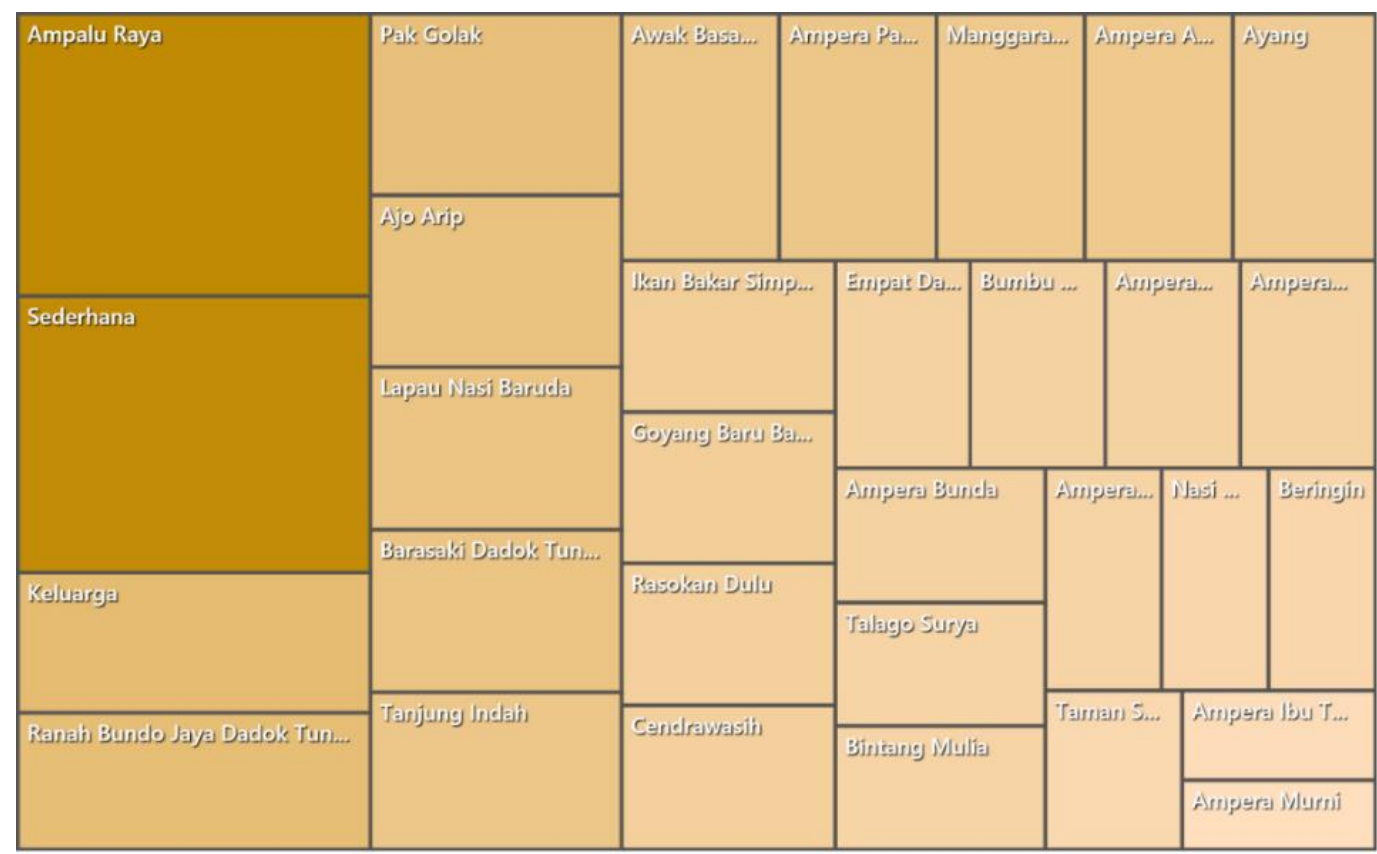

Figure 1. Restaurant Categories Based on the results of the Hierarchy Chart of Nodes

The number of significant restaurant classification is two restaurants. There is also 12 medium and 17 small restaurants which have 525 menu items (an average of 16 menus/classified as medium). The results show the price of food and beverages in medium category is affordable. Yi et al. (2018) also proves that one of influenced consumers factors in buying the product is the price. In this case, the restaurants factory in Padang see that condition as business opportunity named the development of medium category restaurants that fit Minang people needs.

\subsubsection{Food Processing Techniques}

Based on thematic result, it is found five cooking techniques in restaurant food processing such as frying, boiling with coconut milk, burning, and boiling with water and sautéed. There are three themes, mineral water, sachet beverage packaging, and fruit processed (Figure 2).

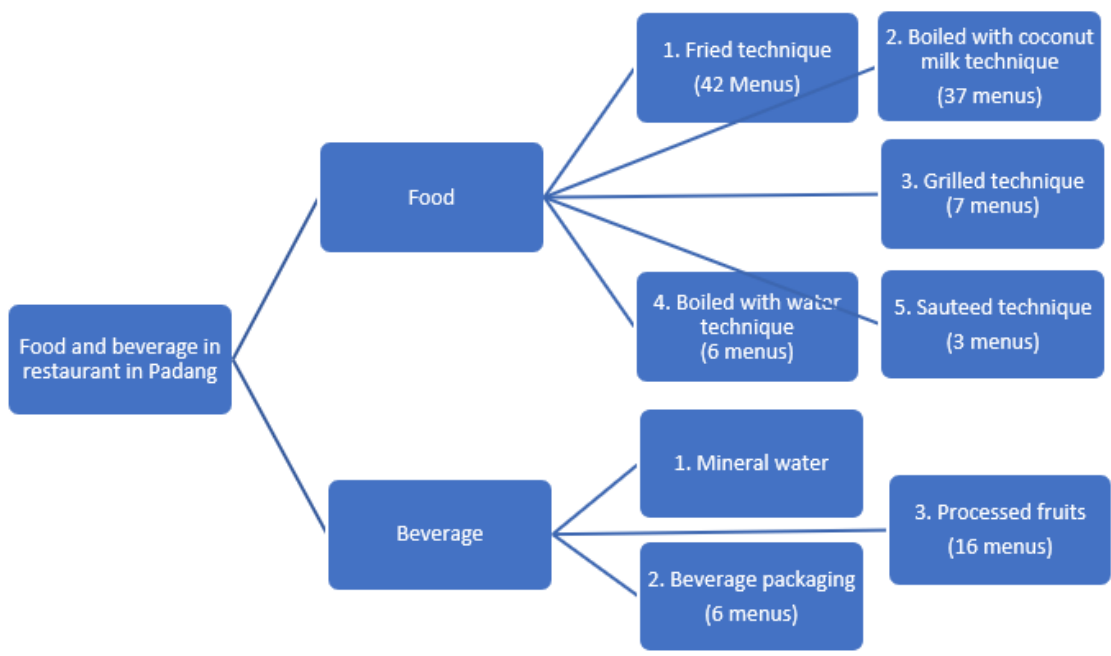

Figure 2. Food Processing Techniques and Beverage Types

Figure 2 shows that there are two dominant cooking techniques named frying technique (42 menus), and boiling with coconut milk (37 menus). The rest are baking techniques ( 7 menus), boiling with water (6 menus), and sautéed ( 3 menus). Vegetable menus are prepared by boiling with water and sautéing techniques, which are only available in some restaurants. Pangestuti \& Rohmawati (2018) report that the consumption of Indonesian people in fried foods is quite high. Based on the results of the 2013 Basic Health Research, the national proportion of Indonesians with the consumption behavior of fatty foods, cholesterol, and fried foods is less than one time per day 40.7 percent. The average level of consumption of fatty foods in West Sumatra is 34.3 percent (Kementerian Kesehatan, 2013). 


\subsubsection{Most Types of Menu}

The restaurants in Padang served variety of food menus from animal and vegetable preparations. They used five kinds of processing techniques. The results show that processed chicken and fish dominate food processing from 95 menus type, Figure 3 shows the 20 menus.

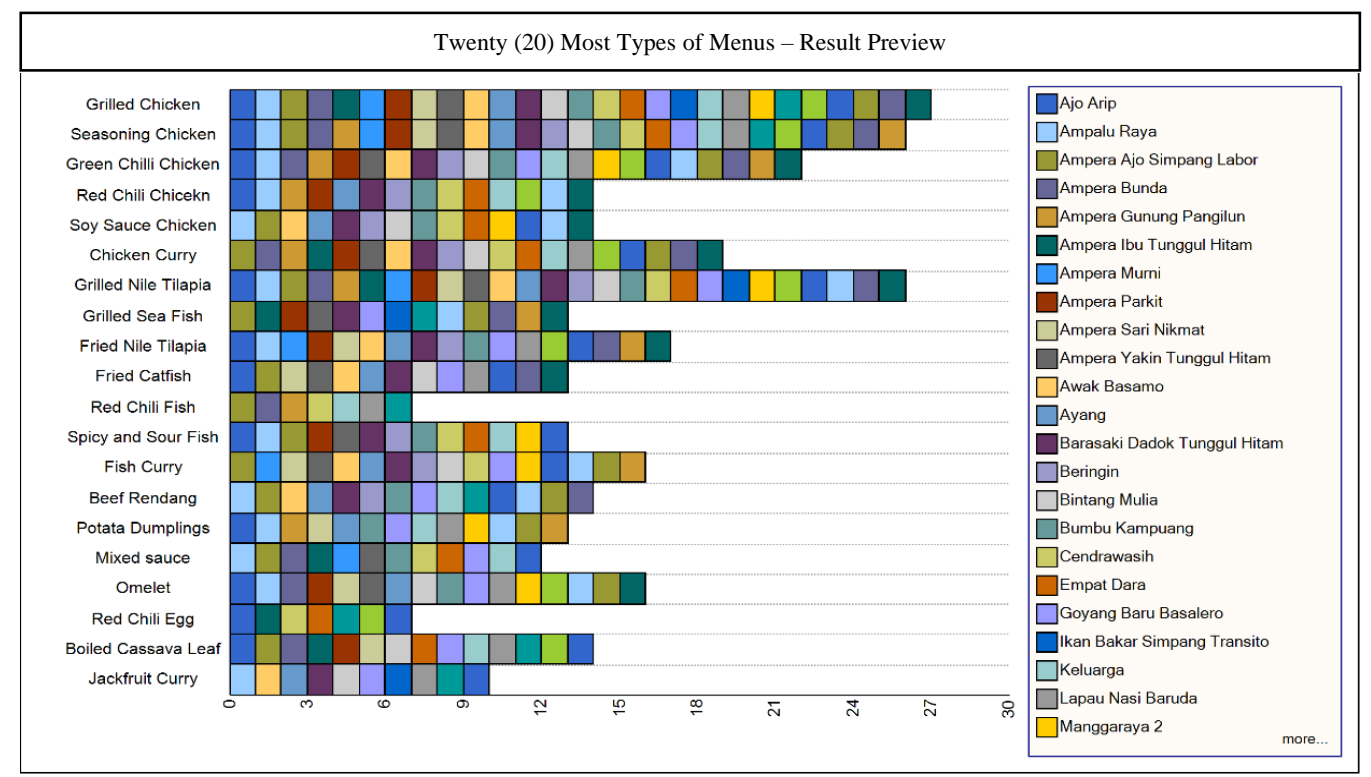

Figure 3. Twenty (20) Most Types of Menus - Result Preview

Figure 3 shows that grilled chicken, seasoning chicken, and grilled tilapia. They are the best seller menu (Ariani et al., 2018). It is reported that chicken is one of Indonesian favourite foods. Indonesia is also one of the largest countries that produce poultry. Many kinds of frying chicken techniques, boiling with coconut milk and baking also grilling \& seasoning chicken of green chili chicken, curry chicken, red chili chicken, soy sauce, rendang chicken, fried chicken flour, chicken pop, chicken curry dates, fried chicken, and penyet chicken.

Apart from chicken, fish is also an animal ingredient that has many processes. Several types of processed fishs are proven the factor of water extent in West Sumatra. A long coastline of West Sumatra Province makes this potential area for fisheries business development. Pond, paddy, and pond fish farming are spread in West Sumatra Province. Several kinds of processed fish such as grilling and frying tilapia, \&curry fish, grilling sea fish, spicy, sour fish, fried catfish, Balado, catfish, sea fish, Balado catfish, coral curry fish, curry fish tilapia.

Processing meat is also a mainstay menu. Ordinary meat is processed by boiling with coconut milk and frying. The most famous processed meat menu is rendang. The results also show that rendang is more favourite processed meat than other processed meats. Dendeng (Jerky) is quite diverse, named dendeng Balado, dendeng cabe hijau, dendeng lambok, and dendeng kering (dried). Other types of processed meats are gulai (curry) tunjang, kalio dagiang (meat), and kurma daging (meat).

Although rendang is known as a typical menu of West Sumatra (Nurmufida et al., 2017), not all restaurants serve this food. According to interviews result with the managers of small category restaurants, they do not serve processed meat every day, but only a few days a week. It is because the price of meat is more expensive than chicken or fish.

\subsubsection{Processed Vegetables at Restaurants in the City of Padang}

The vegetable menu is boiling coconut milk, water, and sautéed. The most common vegetables are Casava Leaves. All restaurant classifications have those menus. It is also as known as gulai nangka (jackfruit curry). The vegetable menu is not very common in restaurants. It is inseparable from low public interest in consuming vegetables. It is In line with Prihatini (2016) research that the consumption of fruits and vegetables in Indonesia is still low, so is it in West Sumatra.

\subsubsection{Processed Drinks at Restaurants in Padang City}

There are three beverages classification in the restaurant. They are mineral water, instant beverages such as sachet product (Milo ${ }^{\mathrm{TM}}$, coffee, tea, Cadbury ${ }^{\mathrm{TM}}$, ginseng), and juice. Mineral water (gallons, glasses, or bottles) is available in every restaurant. Tea, coffee, orange juice, tomato, carrot, avocado, dragon fruit, mango, cucumber, watermelon, guava, yam bean juice, ginseng, Milo ${ }^{\mathrm{TM}}$, 
Cadbury ${ }^{\mathrm{TM}}$. are most common beverages in restaurants. Also juices are usually available in large restaurants. Tea is one of favorite beverages in Indonesia. The price of it is cheaper than other beverage.

\subsection{Identification of Critical Points of Food Failure}

Making flow charts based on recipes are used in sample restaurants. There are the differences of the use of material color. It aimed to differentiate food materials which are being the critical point of halal. The green color indicates that food materials are used without additives or through a processing process that has a critical point. It become halal classification. While the yellow color indicates food contain Food Additives and the contamination from the equipment used. It is doubt of the halal of the equipment used. Figure 4 is an example of a menu flow diagram found in a restaurant, named fish curry and chicken crispy.
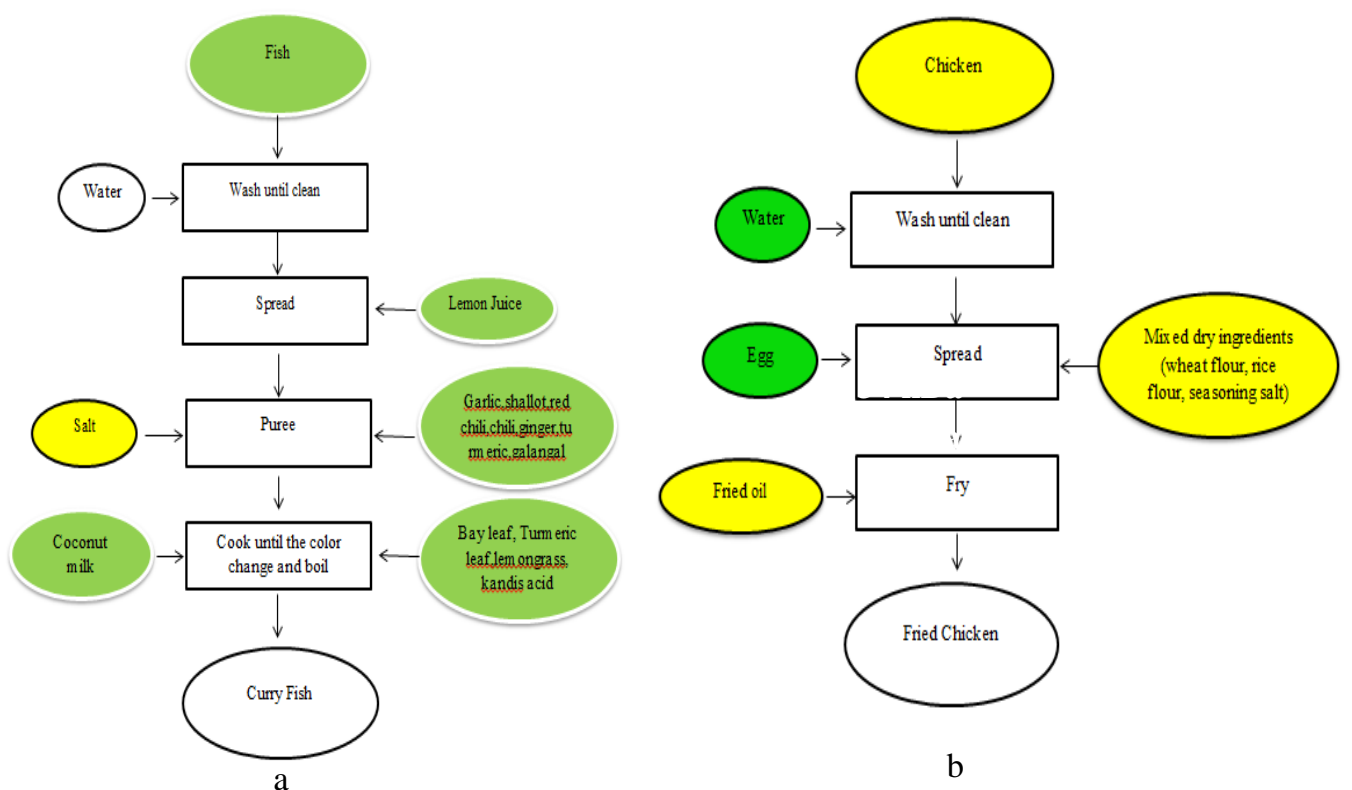

Figure 4. Flour Fish (a) and Chicken Curry Flowchart (b)

Based on the identification of the critical halal point of all foods in restaurants, the critical halal point is arranged into four kinds. They are wet raw material (high water content), dry raw material (water content low), liquid raw materials, and processing equipment (Table 1).

Table 1. Critical Point Halal Food Materials in Padang Restaurants

Sources of Risk in High Water Content Food Materials

\begin{tabular}{|c|c|}
\hline $\begin{array}{l}\text { Beef, mutton chicken, } \\
\text { offal, kikil }\end{array}$ & $\begin{array}{l}\text { - Procedure for the slaughter of animals that do not meet Islamic law } \\
\text { - Contamination impure or unclean material }\end{array}$ \\
\hline Tempe & $\begin{array}{l}\text { - If microbiologically produced using media that is not kosher } \\
\text { - Contamination of process or other ingredients that are harmful and dubious halal } \\
\text { status during the fermentation process such as anti-foam, regulators or growth } \\
\text { stimulants }\end{array}$ \\
\hline Tahu (Tofu) & $\begin{array}{l}\text { - Contamination of process or other ingredients that are harmful and dubious halal } \\
\text { status as coagulant materials, textile dyes, formaldehyde }\end{array}$ \\
\hline
\end{tabular}
Sources of Risk in Low Water Food

Salt - Contamination from other processes or materials dangerous or non-halal such as additives, for example, anti-kempal (anticaking)

Granulated Sugar

- The refining process which involves a resin auxiliary as ion substitute material or a pale material

- using carbon removal Active for color removal

Flavor enhancer If microbiologically produced using non-halal media

Sachets beverage Contamination from other materials such as hazardous and non-halal as preservatives

Wheat flour

- Contamination from other materials such as dangerous and non-halal as improving agents

- If produced microbiologically using non-halal media

Rice flour

Adding ingredients or adding additives which are generally chemicals

Crackers

Adding ingredients or adding additives which are generally chemicals Chemical 


\begin{tabular}{ll}
\hline & Risks Sources for Liquid Foodstuffs and Treatment Equipment \\
\hline Mineral Water & - $\quad$ Contamination of materials hazardous substances \\
Cooking oil & Addition of preservatives, vitamins, purifier \\
Soy sauce, vinegar & - If produced microbiologically using non-halal media \\
& - Contamination from processes or other materials that are dangerous and not halal \\
Mineral Water & - Contamination of ingredients hazardous \\
Smearing Brush & Made from sea urchin or human \\
\hline
\end{tabular}

\subsubsection{Meat (Cow, Goat, Chicken), Offal, Kikil}

The interview results in small and medium restaurants, there is the lack understanding in gaining meat source. It is about the right buther process. First thing first to do of the restaurant in gaining meat is knowing the butcher process. It become one of standardize of halal food. Nevertheless, for Moslems, it should be appropriate with Islamic law (Fuseini et al., 2017).

\subsubsection{Tempe}

Tempe (Rhizopus sp) uses microbes in its manufacture. Based on MUI guidance No. 1 of 2010, microbes are halal as long as they are not harmful and exposed to unclean goods. According to Kurniadi \& Frediansyah (2017), critical point the determining perception of halal products microbialbased bioprocess includes microbial source, isolates, the microbial growth substrate, metabolism products, the production, and matrices or other added ingredients for specific purposes. In the fermentation process, it may be possible in adding something into the component during the process. Then, the traceability of these substances is needed. The results of investigators investigate the Tempe industry in Padang. It is known that there is no critical halal point that can come from manufacturing materials or the processing. It can be concluded that the processing of tempe is halal.

\subsubsection{Tofu}

The process of tofu uses technology. It means that the processes should not contain dirty or another material contamination that can cause the food is not Halal. Sitinjak, R., \& Siagian (2015) explains that there is process and material contamination in one of the tofu factories in Medan. Material contamination comes from soybeans, water, clothing material, and formalin used. The process of contamination also comes from the tools used. The search results show that tofu processing is with harmless ingredients and safety process. It can be concluded that the process of tofu used is halal.

\subsubsection{Salt}

According to Daftar Bahan Tidak Kritis (Halal Positive List of Materials) LPPOM MUI (2013), if there is the addition of additives to the salt, for example, anti kempal (anticaking), it can be unlawful. This material serves to prevent clotting during the storage period. The use of salt is in all processed food. The salt used should have halal label package.

\subsubsection{Granulated Sugar}

The critical point of halal sugar lies in the process of refining (Wojtczak et al., 2012), which involves an ion exchange resin or bleaching agent. The process often involves a phase of color removal using activated carbon. It comes from plants, coal, or animal bones. If activated carbon comes from animal bones, the source should come from halal animals and be slaughtered according to Islamic law (HAS 23201: Persyaratan Bahan Pangan Halal, 2012). Besides, the awareness of it should be done in bleaching agents and sugar clots (Sahu, 2018). The process of beverages use granulated sugar, but some processed food add sugar to them as a natural flavoring. The used sugar has halal labels on the package.

\subsubsection{Flavoring}

According to Kurtanty et al. (2019), Monosodium glutamate (MSG) is one of the favorite instant flavorings used. Glutamic acid is produced through microbial processes from other ingredients as additives. As a microbial product, the critical point might come from three sources. First, the source of the media components used for microbial cultivation, ranging from culture refresher, per inoculum, to the product fermentation media. Second, the source process of auxiliary materials, such as antifoam compounds, harvesting agents spores sometimes use surfactants, cell-breaking agents for removing intracellular products, activating carbon, and ion exchange resins. Third, there is an addition of 
additives to the final product, such as coatings, fillers, $\mathrm{pH}$ regulators, and others (HAS 23201: Persyaratan Bahan Pangan Halal, 2012). Almost all processed food in restaurants use flavoring. The flavoring used has halal label on the package.

\subsubsection{Sachet Packaged}

There are several kinds of sachet pack drinks. They are tea, coffee, cappuccino, ginseng, Milo ${ }^{\mathrm{TM}}$, and Cadbury ${ }^{\mathrm{TM}}$. The critical point of halal sachet beverage packaging is the addition of addictive ingredients. To guarantee its halal status, the packaging requires halal label (Zulfakar et al., 2014). Several kinds of sachet packs process have halal label.

\subsubsection{Wheat Flour}

Flour added by improving agents is susceptible to various contaminants of illicit substances. For example, vitamin B1 (thiamine), vitamin B2 (riboflavin), and folic acid (folic acid) sourced from plants are halal to be consumed. These vitamins change the status to become not Halal (Haram) if there is the use of non-halal media to produce microbiologically. Besides, the use of lecithin in flour also become the concern if it contains forbidden ingredients (Dogan et al., 2018). The flour used already has halal label.

\subsubsection{Rice Flour}

Rice flour is derived product from vegetable materials through the physical process without the addition of ingredients or the addition of additives, which are chemicals. Halal requirement of rice flour is halal certification. Based on the identification results, processed food by using rice flour with fried techniques. They are chicken fried, flour, fried catfish. Rice flour used in restaurants already has halal label.

\subsubsection{Crackers}

According to Moelyaningrum (2019), the critical point of halal crackers is if there is the addition of vitamins, preservatives bleach, or boric acid. It causes those food products contain danger ingredients. Also, there is a critical point of halal in the processing of crackers, such as the drying process which is carried out in the oven (Pratidina et al., 2018). The crackers at the restaurant still do not have halal composition and label. It is need the identification of halal status.

\subsubsection{Mineral Water}

Koelmans et al. (2019) \& the World Health Organization (2019), reports that there are drinking water and water sources that are contained microplastic. It become danger for human health. Besides, it should be aware of pre-filter filtering process with activated carbon filters by using unclean animal bone waste (Salleh et al., 2017). The results showed that some restaurants provide bottled mineral water, glass bottles, and refill mineral water. They already have halal label on the packaging. However, there is no halal guarantee of water from refill gallons because there are no halal certificate in drinking water depots in Padang.

\subsubsection{Cooking Oil}

Cooking oil is from vegetable oil or animal oil, which in the processing involves pale material in the form of bleaching earth or activated charcoal and the addition of antioxidants. It makes halalcertified should be required in oil production process (HAS 23201: Persyaratan Bahan Pangan Halal, 2012). According to Sugito et al. (2018), some producers mix vegetable cooking oil with animal oil to produce more savory food taste. Mohammed et al. (2012) state that produces adsorbents in palm oil can use pig bones. Restaurants use more packaged oils that have halal labels. However, there are still restaurants, especially small category restaurants, which still use uncertain bulk oil.

\subsubsection{Soy Sauce and Vinegar}

The fermentation process has an impact on halal status of food products, because it uses microbial assistance in its manufacture (Faridah \& Sari, 2019). Vinegar is one of the products whose production process uses microbes (Budak et al., 2014). Soy sauce is also one of the food products are made through the fermentation process of soybeans, using yeast or tempeh mushrooms and added various ingredients such as herbs and spices, sugar, and water (Park et al., 2017). If soy sauce and vinegar have used halal label on their packaging, halal is guaranteed.

\subsubsection{Brush}

The use of a brush is for spreading seasoning on burned food. The brush used should be made of synthetic (such as plastic) and animal hair that is halal. Also the butcher process is according to 
Islamic law (Yusoff et al., 2015). Some brands used polishing brushes. They are made from pig hair and human hair. The use of brush in the restaurants in Padang is still unknown of the halal status. It is because there is no halal label.

\section{Conclusion}

Ampalu Raya restaurant (47 menus) is the restaurant with the most menus and the Ampera Murni restaurant ( 7 menus) is the least. Five food processing techniques are fried, boiled with coconut milk, baked boiled with water, sautéed. The beverage menu consists of mineral water, sachets, and juice. Grilled chicken, seasoned chicken, and grilled tilapia are the most menus, while rendang is a mainstay sourced from beef, but not all restaurants can serve it everyday. Food Materials that have strong halal critical point are meat (slaughtering techniques), crackers, bulk oil, mineral water, and brushes. The restaurants in Padang is still lack knowledge of the critical point of halal meat, which can come from the butcher process. While the absence of halal composition and labels on crackers and bulk oil packaging is the main factor that makes this food has strong halal critical point. There are still restaurants that provide mineral water from refill drinking water depots that are not halal certified. Dauber brushes used in restaurants also do not have a halal label. Other Food Materials already have halal label on the packaging.

\section{References}

Ariani, M., Suryana, A., Suhartini, S. H., \& Saliem, H. P. (2018). Keragaan Konsumsi Pangan Hewani Berdasarkan Wilayah dan Pendapatan di Tingkat Rumah Tangga. Analisis Kebijakan Pertanian, 16(2), 147. https://doi.org/10.21082/akp.v16n2.2018.147-163

Arikunto, S. (2019). Metodologi penelitian. Jakarta: Rineka Cipta.

Aspers, P., \& Corte, U. (2019). What is Qualitative in Qualitative Research. Qualitative Sociology, 42(2), 139-160. https://doi.org/10.1007/s11133-019-9413-7

Budak, N. H., Aykin, E., Seydim, A. C., Greene, A. K., \& Guzel-Seydim, Z. B. (2014). Functional Properties of Vinegar. Journal of Food Science, 79(5). https://doi.org/10.1111/1750-3841.12434

Colombijn, F. (1996). City Profile Padang. The International Journal of Urban Policy and Planning, 13(4), 281-288.

Dogan, C. E., Cebi, N., Develioglu, A., Olgun, E. O., \& Sagdic, O. (2018). Detection of cystine and cysteine in wheat flour using a robust LC-MS/MS method. Journal of Cereal Science, 84, 4954. https://doi.org/10.1016/j.jcs.2018.09.015

Faridah, H. D., \& Sari, S. K. (2019). Utilization of Microorganism on the Development of Halal Food Based on Biotechnology. Journal of Halal Product and Research, 2(1), 33. https://doi.org/10.20473/jhpr.vol.2-issue.1.33-43

Fuseini, A., Wotton, S. B., Hadley, P. J., \& Knowles, T. G. (2017). The perception and acceptability of pre-slaughter and post-slaughter stunning for Halal production: The views of UK Islamic scholars and Halal consumers. Meat Science, 123, 143-150. https://doi.org/10.1016/j.meatsci.2016.09.013

Kementerian Kesehatan. (2013). RISET KESEHATAN DASAR: In RISKESDAS 2013. https://doi.org/10.1517/13543784.7.5.803

Koelmans, A. A., Mohamed Nor, N. H., Hermsen, E., Kooi, M., Mintenig, S. M., \& De France, J. (2019). Microplastics in freshwaters and drinking water: Critical review and assessment of data quality. Water Research, 155, 410-422. https://doi.org/10.1016/j.watres.2019.02.054

Kurniadi, M., \& Frediansyah, A. (2017). Halal Perspective of Microbial Bioprocess Based-Food Products. Reaktor, 16(3), 147. https://doi.org/10.14710/reaktor.16.3.147-160

Kurtanty, D., Faqih, D. M., \& Upa, N. P. (2019). Review Monosodium Glutamat How to Understand it Properly? In Journal of Chemical Information and Modeling (Vol. 53, Issue 9).

Lau, A. N., Jamaludin, M. H., \& Mei Soon, J. (2016). Quality assurance and halal control points for the food industry. Nutrition and Food Science, 46(4), 557-570. https://doi.org/10.1108/NFS-032016-0026

LPPOM-MUI. (2018). Peluncuran The Indonesia Halal Life Style and Business. Retrieved from https://halalmui.org/mui14/main/article/berita

HAS 23201: Persyaratan bahan pangan halal, (2012). Retrieved from https://www.halalmui.org/mui14/main/page/e-book-persyaratan-sertifikasi-halal

Daftar Bahan Tidak Kritis (Halal Positive List of Materials) LPPOM MUI. (2013). Retrieved from https://www.halalmui.org/images/stories/pdf/SKdirektur/SK07.I.2013-Daftar Bahan Tidak 
Kritis (Halal Positive List of Materials).pdf

Maguire, M., \& Delahunt, B. (2017). Doing a Thematic Analysis: A Practical, Step-by-Step Guide for Learning and Teaching Scholars. All Ireland Journal of Teaching and Learning in HIgher Education, 8, 3135-3140. https://doi.org/10.1109/TIA.2014.2306979

Miles, M. B., Huberman, A. M., \& Saldana, J. (2019). Qualitative Data Analysis: A Methods Sourcebook. SAGE Publications.

Moelyaningrum, A. D. (2019). Boric acid and hazard analysis critical control point (HACCP) on kerupuk to improve the indonesian'S traditional foods safety. International Journal of Scientific and Technology Research, 8(6), 50-54. https://doi.org/10.31227/osf.io/grftm

Mohammed, A., Aboje, A. A., Auta, M., \& Jibril, M. (2012). A Comparative Analysis and Characterization of Animal Bones as Adsorbent. Advances in Applied Science Research, 3(5), 3089-3096.

Neio Demirci, M., Soon, J. M., \& Wallace, C. A. (2016). Positioning food safety in Halal assurance. Food Control, 70, 257-270. https://doi.org/10.1016/j.foodcont.2016.05.059

Nurmufida, M., Wangrimen, G. H., Reinalta, R., \& Leonardi, K. (2017). Rendang: The treasure of Minangkabau. Journal of Ethnic Foods, 4(4), 232-235. https://doi.org/10.1016/j.jef.2017.10.005

Olya, H., \& Al-Ansi, A. (2018). Risk Assessment of Halal Products and Services: Implication for Tourism Industry. Tourism Management, 65, 279-291. j.tourman.2017.10.015

Park, S. W., Lee, S. J., Sim, Y. S., Choi, J. Y., Park, E. Y., \& Noh, B. S. (2017). Analysis of ethanol in soy sauce using electronic nose for halal food certification. Food Science and Biotechnology, 26(2), 311-317. https://doi.org/10.1007/s10068-017-0042-1

Perdana, P. (2019). Wisata Halal Sumbar, Ini 22 Rumah Makan yang Direkomendasikan Dinas Pariwisata. Retrieved from https://regional.kompas.com/read/2019/07/03/14031671/wisatahalal-sumbar-ini-22-rumah-makan-yang-direkomendasikan-dinas?page=all

Pratidina, G. E., Santoso, H., \& Prastawa, H. (2018). Perancangan Sistem Hazard Analysis Critical Control Point (HACCP) dan Sistem Jaminan Halal di UD Kerupuk Ikan Tenggiri Dua Ikan Jepara. Industrial Engineering Online Journal, 7(4).

Prihatini, H. (2016). Gambaran Konsumsi Sayur dan Buah Penduduk Indonesia dalam Konteks Gizi Seimbang: Analisis Lanjut Survei Konsumsi Makanan Individu (SKMI). Buletin Penelitian Kesehatan, 44(3), 4-10.

Sahu, O. (2018). Assessment of sugarcane industry: Suitability for production, consumption, and utilization. Annals of Agrarian Science, 16(4), 389-395.

Salleh, M. M. M., Deuraseh, N., Subri, I. M., Rahman, S. A., Mustafa, S., Jamaludin, M. A., \& Safian, Y. H. M. (2017). The Use of Ceramic Product Derived from Non-Halal Animal Bone: Is it Permissible from the Perspective of Islamic Law? International Journal of Asian Social Science, 7(3), 192-198. https://doi.org/10.18488/journal.1/2017.7.3/1.3.192.198

Sitinjak, R., \& Siagian, A. (2015). Analisis Bahaya dan Identifikasi Titik Kritis pada Industri Rumah Tangga Pembuatan Tahu Cina Dan Tahu Sumedang di Kelurahan Sari Rejo Kecamatan Medan Polonia. Gizi, Kesehatan Reproduksi Dan Epidemiologi, 1(1), 2015.

Sovia, F., Rini, D., P.Lubis, D., Susanto, D., \& Soetarto, E. (2018). Portrait of The Minangkabau Culture According to Hofstede's Six Cultural Dimensions. Sodality: Jurnal Sosiologi Pedesaan, 6(2). https://doi.org/10.22500/sodality.v6i2.23229

Srivastava, K. (2015). A Study of Attributes Affecting Selection of Restaurants by Selected Customers. International Journal of Home Science, 46(1), 46-51.

Sugito, H., Firdausi, K. S., \& Putri, N. K. (2018). Evaluasi Cemaran Lemak Babi Pada Minyak Goreng. 4(1), 1-4.

Wojtczak, M., Biernasiak, J., \& Papiewska, A. (2012). Evaluation of microbiological purity of raw and refined white cane sugar. Food Control, 25(1), 136-139.

Yi, S., Zhao, J., \& Joung, H. W. (DAVID). (2018). Influence of price and brand image on restaurant customers' restaurant selection attribute. Journal of Foodservice Business Research, 21(2), 200-217. https://doi.org/10.1080/15378020.2017.1368808

Yusaini, H. M., Abd Rahman, A. R., Azanizawati, M., \& Mohd Ghazli, H. (2016). Halal Traceability in Enhancing Halal Integrity for Food Industry in Malaysia - A Review. International Research Journal of Engineering and Technology, 3(3), 68-74.

Yusoff, A. M., Yusof, F. N. R., \& Raja Rahayu Hussin, S. (2015). IJEM International Journal of Economics and Management Halal Food Supply Chain Knowledge and Purchase Intention. 
International Journal of Economics and Management, 9(S), 155-172.

Zulfakar, M. H., Anuar, M. M., \& Talib, M. S. A. (2014). Conceptual Framework on Halal Food Supply Chain Integrity Enhancement. Procedia - Social and Behavioral Sciences, 121, 58-67. https://doi.org/10.1016/j.sbspro.2014.01.1108

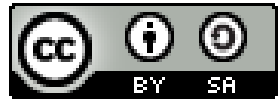

(C) 2022 by the authors. Submitted for possible open access publication under the terms and conditions of the Creative Commons Attribution (CC BY SA) license (https://creativecommons.org/licenses/by-sa/4.0/). 